\title{
Wealth Creation Through Real Estate Investment in Ekiti State
}

\author{
Olajide S. E. \\ Dept. of Estate Management, \\ Federal Polytechnic, Ado-Ekiti, Ekiti State \\ Tel:+234(0)8038552016E-mail: (sundayolajide2012@gmail.com) \\ Alabi, O. Titilayo \\ Dept. Of Estate Management, \\ Yaba College Technology, Yaba, Lagos, Nigeria \\ Tel:+234(0)8023430725.E-mail:woletborn@yahoo.com \\ Onakoya, B. O. \\ Dept. Of Estate Management, \\ Federal Polytechnic, Ilaro, Ogun State, Nigeria. \\ Tel:+234(0)8125098064E-mail: tundeonakoya@yahoo.com
}

Doi:10.5901/ajis/2013.2n1p417

\section{Abstract}

Wealth creation has been described as a strategic implementation of policies meant to contribute to poverty eradication and thereby focusing on self-empowerment and wage-employment. This goes a long way in boosting the economy. The writers therefore look into real estate investment as one of the major ways of creating wealth in Ekiti State, Nigeria. This was done by x-raying the various facets of real estate where wealth could be created like land titling and registration, rating and taxation, property development and management among others. Challenges associated with the effective and efficient exploration and exploita tion were examined with frantic effort towards tackling them.

Keywords: Ekiti Estate, Investment, Poverty, Real Estate, Wealth Creation.

\section{Introduction}

The subject 'Wealth creation' came to being as a result of much clamoring of the word "poverty" in the developing and Third World Countries. Enough evidences had emerged to prove that most of these nations are wallowing in abject poverty which extends to almost every facet of the economy. Poverty is a household word in Nigeria and has been defined in diverse ways by various authorities. According to Olajide and Onifade (20II), Poverty is seen as " a state of being poor......., lack of something. Akagha (2006) asserted that poverty is an imposition from an external force as nobody has chosen to be poor. It is only a matter of circumstance that one is poor.

Essentially, poverty environment in Nigeria represents a paradox, if one takes into consideration that quality of human resources as well as the extent of material endowments of the country. The country's demographic feature, as containing about twenty percent of the total population of Africa as well as the contributions of its crops of intellectuals in global affairs, coupled with its strategic 
significance as the sixth largest oil producer in the world, ranks it as a major global player. Olaifa (I988) described Nigeria as black Africa's richest state which once reveled in oil boom, and ended up with a massive debt as a result of mismanagement of economy, neglect of agriculture and numerous political upheavals.

Wealth creation has been proffered as the only antidote to poverty. It is a general belief that creating wealth and prosperity is the way forward to a better life. This will naturally witness dramatic growth in the standard of living and it is easily evident that much development has brought much wealth and prosperity to the people. However this specious belief has been severally criticized especially in the developed nations in that wealth creation in the recent past has transpired in good number of advanced countries that wealth has mostly been created for the upper echelon of society, by gross indulgence in acts of cheating and corruption.

Ekiti State has been seen as one of the youngest states to be created in Nigeria and funny enough a civil servant state. There is no evidence of industrial developments or presence in the state, hence, the economy of the state had been at the lowest ebb. However evidence has shown that the State is blessed with a good array of resources that can transform the State from its abject poverty to a more prosperous one. Overdependence on the Federal Allocation has not helped matter.

Hence, it is the intention of this paper to critically look at real estate investment as one of the major avenues available for Ekiti State to create wealth that will bring about sudden economic transformation.

\section{Concept of Real Estate}

Olajide and Alabi (2012) opined that real estate is synonymous with real property as well as land and landed property. They submitted that real estate can take the form of land and / or landed property, that is, any development in land. Olajide and Alabi (2012) defined real Estate or property as any personal belonging with title which can be conveyed and reconvened at law with a distinguishing characteristic of immobility. Examples of real estate include land and buildings.

To define 'Land' Akomolede (2009) believed that the definition of land would generate controversies as he believed that 'LAND' means different thing to different people. For instance, to the geographer, land is the solid surface of the earth not covered by water but to the economists, land is one of the factors of production. The others being labour, capital and entrepreneur.

To the kings or governments, land is seen in terms of a territorial domain. The meaning of land can even become more complex if one looks at the law which says "quic quid plantatur solo solo credit' which means whatever is permanently attached to the land is part of land and whosoever owns the land owns everything on, over and under it. But we do know that under the Nigerian constitution, it is not entirely so as mineral found in one's land does not belong to the owner but to the Government. To an Estate Surveyor and Valuer, Land refers to the subtotal of both the natural and man-made resources on the land surface over which possession gives control.

From the above, one can see that land could be given so many meanings depending on who is speaking and the occasion.

Akomolede (2009) went further to examine the various uses of land to man to include:

We need land for agricultural purposes. Without agriculture, we shall not be able to feed and without food, we cannot live. It does not matter whether the food is produces locally or imported.

All houses are built on land whether one will want to build a sky-scraper or otherwise, no building can stand except on land.

All our transportation requires land. Roads and rail lines are built on land while the air and sea ports without which we cannot travel by air or sea are also built on land. 
All our recreational activities take place on land. It could be outdoor like football, lawn tennis, swimming or golf or indoor like badminton, squash, snooker, dancing, etc are rooted on land.

All commercial activities like market places, shopping centres, plazas and supermarkets are located on land

All industrial activities are also located on land. Factories with their plants and machineries are all fixed to the surface of land.

He argued that effective and efficient use of land as well as its resources would in no small measure transform to wealth creation to individuals, families, cities and the nation at large.

\section{Concept of Wealth Creation}

Ojo (2009) Posited that the issue of wealth creation could be viewed within the threshold of selfemployment (empowerment), wage employment. The two jointly referred to as welfare and poverty reduction (Adebayo, 2005).

Mutabwire (2008) described wealth creation as strategic implementation of policies meant to contribute to poverty eradication, focusing on: Improving local governance for sustainable local economic growth;

Employment creation; increased production and productivity of enterprises; increased incomes; and

broadening of tax base for local governments to deliver the mandated services.

It is a strategy towards the enhancement of local economic development in order to increase local incomes and expand local revenue bases.

Zanzibar Household and Budget survey (2004) explained that wealth creation entails national efforts to accelerate growth and create employment by empowering the poor and vulnerable groups to participate in and benefit from emerging opportunities.

Wealth creation as put by Ojo (2009) entails empowerment as a fundamental goal to help individuals within the society to improve the quality of their own lives and share equitably in the benefits of economic growth. Empowerment is about helping people to unleash their creative and productive energies to achieve sustainable growth and continuous improvement in their living standards. The concept goes beyond the notions of democracy, human rights and participation, to include enabling people to understand the reality of their environment (social, economic, political, ecological and cultural) and to take necessary actions to improve their well-being. Adebayo (2005) further described wealth creation in terms of welfare. Encarta Encyclopedia (2005) referred to it as social security programmes. Within the same context, improvement in welfare was considered synonymous with reduction in poverty. Poverty alleviation is supposedly the main thrust of wealth creation. Wealth creation or prosperity is purely an economic phenomenon.

In Nigeria, various programmes as highlighted below had been inaugurated toward the betterment of living and wealth creation (Ariyo 1997, Adebayo, 2005). Between I986 - 1993, Directorate of Food, Roads and Rural Infrastructure (DFRRI), was formulated to embark on the tasks of constructing feeder roads, electrification of communities, provision of potable water and empowerment of people. Between 1987-1993, there was establishment of a programme called Better Life Programme with the following tasks: agricultural programme, development support programmes, market support services, establishment of cottage industries and clinics. Between 1997-I999, Family Economic Advancement programmed (FEAP) was formulated to financially support society. With the above enumerated developmental programmes, the symptom of poverty still persists in the society. Against the foregoing, real estate is perceived as a potential avenue to create wealth and eliminated poverty in the country. 
Wealth creation from the public perspective can be referred to as the effort of government to generate revenue for public infrastructural (Adebayo 1970, Diejomaoh, 1976, Emenuga, 1993, Ariyo, 1997).

\section{Housing Needs in Nigeria}

According to Olotuah and Adedeji (2009), the pooled effect of high population upsurge and urbanization in a declining economy has thrown Nigeria into serious housing problems. Ironically, the low income groups who constitute the majority in the Nigeria society are the most affected by the housing menace. The problems of housing shortage grow worse by the day in many developing nations including Nigeria. Conceivably, a major trait of housing crisis notable in urban centres in most developing nations is that of inadequate supply relative to demand (Olotuah, 2000). Using various assumptions of urbanization rates, Onibokun (1990) estimated the following figures as summarized in figure one below

Table I: Estimated Housing Needs Between The Period Of 1990-2020

$\begin{array}{lccc}\text { Income Group } & 1990 & 2000 & 2020 \\ \text { Low income } & 8,413,980 & 14,372,293 & 39,989,286 \\ \text { Medium income } & 7,770,005 & 13,273,291 & 33,573,900 \\ \text { High income } & 7,624,230 & 12,419,068 & 28,548,633\end{array}$

Sources: Onibokun, I990

Shortage of adequate housing virtually abounds in every country, particularly in the developing and third world countries. The shortage in both quantitative and qualitative terms is more acute in the urban centres. Omojinmi (2000) observed that people that sleep in indecent houses in urban Nigeria are more than people who sleep in decent houses. Thus, it is assertive that there is inadequacy in housing to cope with the ever-increasing population in Nigeria (Arayela, 2003). This in essence opens a good avenue for real estate investment in Nigeria in general and Ekiti State in particular.

\section{The Study Area}

Ekiti State is a state in Southwest Nigeria declared a state on October I, I996 alongside five others. The state carved out of the territory of old Ondo State covers the former twelve local government areas that made up the Ekiti zone of old Ondo State. On creation, it took off with sixteen (I6) Local Government Areas (LGAs) having had an additional four carved out of the old ones.

Historically, Ekiti was an independent state prior to the British conquest. It was one of the many Yoruba States in what is today Nigeria. Ekiti as a nation and districts of Yoruba race had her progeny Oduduwa, the father and progenitor of Yoruba race. Ekiti land is surrounded by hills where it derived it name. initially Ekiti was known as "Ile Olokiti" mean land made up of hills. Therefore the Okiti later blended to Ekiti, so, Ekiti derived her name through hills.

Geographically, the state is mainly an upland zone, rising over 250 meters above sea level. It lies on an area underlain by metamorphic rock. It is generally undulating with a characteristic landscape that consists of old plains broken by step-sided out-crops that may occur singularly or in groups exist mainly at Aramoko, Efon-Alaaye, Ikere-Ekiti, Igbara-Odo, and Okemesi Ekiti,

The state enjoys tropical climate with two district seasons. These are the raining season (April October) and the dry season (November - March). Temperature ranges between $2 \mathrm{I}^{\circ}$ and $28^{\circ} \mathrm{C}$ with high humidity. Ekiti is estimated in 2005 to be about 2, 737, 186 ranks $29^{\text {th }}$ of 36 States. Ekiti is located within the coordinates of $7^{\circ} 40^{\prime} \mathrm{N}$ and $5^{\circ} \mathrm{I} 5^{\prime} \mathrm{E}$. 
From the foregoing, there is no gainsaying that Ekiti is rapidly growing in population and requires other sources of revenue for economic stability. Hence the need for this research work which tends to recommending real estate investment as a veritable source of wealth creation.

\section{Research Methodology}

Both primary and secondary data were made used of in carrying out the research work. Primarily, structured questionnaire were administered on different professionals in the Building industry. A total number of 50 copies were served but 45 were retrieved. Direct interview and observations were also employed. The bulk of the data came through review of relevant literature. Also, the purposive sampling was adopted in that professionals that have stake in the real estate investment were directly interviewed on the subject matter. The method of data analysis is by the use of tables and simple statistical analysis.

\section{I Data Presentation of Analysis}

Having in mind the intention of determining the degree of government participation in real estate development in Ekiti State, effort is made below to analysis in simple form some of the data collected.

Table 2: Percentage of NHF Beneficiary

\begin{tabular}{|c|c|c|c|}
\hline Year & No of Contributors & No of Beneficiary & No \% of Beneficiary \\
\hline 2000 & $1,285,157$ & 349 & 0.027 \\
\hline $200 \mathrm{I}$ & $1,857,279$ & 2,043 & 0.110 \\
\hline 2002 & $1,863,995$ & 2,286 & 0.123 \\
\hline 2003 & $1,900,126$ & 2,079 & 0.109 \\
\hline 2004 & $1,728,222$ & 2,081 & 0.120 \\
\hline
\end{tabular}

Sources: FMBM Status Report, 2005

Table 2 above shows a very low response of the Federal Mortgage Bank of Nigeria as well as the Primary Mortgage Institutions (PMIs) to the yearning of intending real estate developers to having access to affordable real estate finance system.

Table 3: Application and Approval of Land Allocation Granted Between 2002 to $201 \mathrm{I}$

\begin{tabular}{|c|c|c|c|}
\hline Year & Application Received & $\begin{array}{c}\text { Allocation } \\
\text { Granted }\end{array}$ & $\begin{array}{c}\text { Percentages of Allocation } \\
\text { Granted }\end{array}$ \\
\hline 2002 & 376 & 95 & $25.27 \%$ \\
\hline 2003 & 701 & 47 & 6.70 \\
\hline 2004 & 986 & 192 & 19.47 \\
\hline 2005 & $\mathrm{I} 218$ & $3 \mathrm{I}$ & 2.55 \\
\hline 2006 & $\mathrm{I} 339$ & 247 & 16.05 \\
\hline 2007 & 672 & 15 & 2.23 \\
\hline 2008 & 522 & $\mathrm{II}$ & $2.1 \mathrm{I}$ \\
\hline 2009 & $34 \mathrm{I}$ & 19 & 5.57 \\
\hline 2010 & $7 \mathrm{I} 6$ & 28 & $3.9 \mathrm{I}$ \\
\hline $201 \mathrm{I}$ & 857 & 206 & 24.04 \\
\hline TOTAL & 7928 & $89 \mathrm{I}$ & 11.24 \\
\hline
\end{tabular}

Sources: Ekiti State Bureau of Lands, 2012 
Table 3 above shows that the highest percentage that had so far been granted is $25 \%$ of the total application for government land in a year. For the last ten years, a total of 7,928 applications were submitted with only 89I approved for allocation. This represents a total parentage of II.24\%. This seems to be grossly inadequate.

Table 4: Quantum of Agricultural Land in Ekiti

\begin{tabular}{|l|c|c|}
\hline Land use type & Area of land in $\mathrm{Km}^{2}$ & Percentage \\
\hline Agric land & 4560 & 71.78 \\
\hline Non Agric Land & 1,793 & 28.22 \\
\hline Total & 6,353 & 100.00 \\
\hline
\end{tabular}

Source: Ministry of Physical Planning and Urban Development (20I2)

Table 4 above shows that 71.78\% of the entire land area of Ekiti is ripe and good for Agricultural uses. Findings also showed that not up to $15 \%$ of the $4560 \mathrm{~km}^{2}$ of the total area available for agricultural is currently utilized notwithstanding the benefit derivable from Agricultural Land like abundant food production, provision of raw materials for industries and increased foreign exchange among others.

Table 5: Existence of a Standard Land Tax System

\begin{tabular}{|l|c|c|}
\hline Item & Frequency & Percentages \\
\hline Yes & 5 & II.II \\
\hline No & 36 & 80.00 \\
\hline Indifferent & 4 & 8.89 \\
\hline Total & 45 & 100.00 \\
\hline
\end{tabular}

Sources: Field Survey by Authors 2012

From table 5 above, it can be seen that there is no evidence of a standard land tax system in Ekiti. This is not good enough.

Table 6: Sources of Real Estate Finance for Intending Developers

\begin{tabular}{|l|c|c|}
\hline sources & Frequency & Percentages \\
\hline Personal savings & 4 & 8.88 \\
\hline Bank loan ( Mortgage) & 3 & 6.67 \\
\hline Credit society (cooperative) & 35 & 77.78 \\
\hline Communal Effort & 3 & 6.67 \\
\hline Total & 45 & 100.00 \\
\hline
\end{tabular}

Sources: Field Survey by Authors 2012

Table 6 above shows the reality on ground in the area of developers' access to Bank loan to aid development. The table evidences that less than $7 \%$ of the sampled population had access to bank loan while majority depend of credit societies (77.78\%). This implies that Ekiti State has a lot to do in the area of strengthening real estate finance system. 


\section{Significance and Justification of Real Estate for Wealth Creation}

This is best discussed under the following headings.

\section{I. Land Taxation:}

Property Valuers, the world over, use variables reflecting collective services, including proximity to public transport, quality of infrastructure, local schools, etc as key determinants of property values. It is common cause that a significant component of land value is not earned by the effort of land owner or occupant, but result directly from collective action, even from the mere presence of an organized community, regardless of the quality of services it currently provides for its members (Childress et al, 2007). As such, the incumbent owner of the land has, in the neo-Georgist view, no moral right to claim increments in the value of his or her own, nor any cause for complaint if a tax on land value is instituted to capture such value for the benefit of the entity that was responsible for its creation; community; government and its partners. Essentially, land taxes have been used for a wide variety of reasons. Among the reasons are:

Ensuring productive use of restituted land. Land taxes have been imposed to ensure the productive use of restituted land in Estoma (Childress et al, 2007).

Creation of property rights. In most of the transitional countries there had been no well- defined property rights in land for several decades. The land tax and property tax, based on clear assessment and valuation processes, was seen as a mechanism that would consist in the development of local land markets and a local brokering and property based lending industries both in the rural and urban areas (Hopfer, 2003)

Creation of land valuation capacity. The need to conduct formal, well organized valuations requires a cadre of trained officials who have knowledge and active understanding of the markets. This provides a mechanism of transmitting an understanding of the transformation which will be a core requirement of the development of urban and agricultural property market.

Buildings on existing taxation system. According to Childress et al (op cit) in Armenia, the fiscal system was shifted away from business income taxes to an enhancement of the existing property tax system, which was based heavily on land values.

Discouraging foreign absentee ownership. In Australia, land taxation has been used to discourage foreign absentee land ownership (Land Institute, 1974). Wilk (I973) suggested that land tax could be used to discourage the vacant holding of land by foreign buyers.

Saving on assessment costs. Childress et al (2007) revealed that saving on assessment costs was one of the reasons for the adoption of a land taxation system in Kenya and South Africa (before the recent shift away from "land only" to "land and improvements"). In general, land valuation is much cheaper than the valuation of buildings, both in the urban and rural areas, requiring less data and fewer site visits by valuers.

Land taxation can be used to manage political tensions around land. Malme and Youngman (1997) established that in China and the transitional states of the former Soviet Union, the once dominant rights of the state are being dismantled in favour of individual property rights.

In fact, the land tax offers an effectual bridge across this public policy divide, as it can address a number of the concerns on both sides. Land taxes can thus present a combination of state and personal rights in the land heritage of the nation. 


\subsection{Wealth creation through efficient use of land}

The Oxford English Dictionary describes the word effective as "producing the result that is wanted or intended; producing a successful result" while efficient is described as "doing well and thoroughly with no waste of the money or energy".

From these definitions, it is clear that we are looking for a system of land use that will produce the wanted or intended result as well as do well without any waste. That will be an effective and efficient use of land. Our mission here is therefore simply to discuss how we can use this God's limited gift to produce the desired results without any waste. Obviously, the first major aim or intended result of land use is to produce a harmonious and orderly use of land. And this can only be done if we avoid haphazard development. This therefore brings us to the fore of land use planning.

For the use of land to be effective and efficient, we must plan the use of land to produce an orderly and harmonious development. To this end, the following aspects of land use must be handled with care to enhance productivity. This includes zoning, compatibility land use, best and highest use to mention a few.

\subsection{Wealth creation through land reform}

Much have been said and written about the need for adequate land titling in all states of the federation. It is a statement of fact that Government has a lot to gain from land titling especially in the area of boosting its IGR. Statistics show that less than I0\% of the land situated within Ekiti has legal title. This, if well effected will assist the land owners to carryout productive transactions on their land that will boost their economic stability.

\subsection{Wealth creation through the exploitation of agricultural lands}

Findings had shown that the Agricultural Land in Ekiti State is enormous but it is sad to note that less than $20 \%$ of this landmass is being made use of. Much is derivable from effective exploitation of Agricultural lands. The state can become exporter of cassava, palm oil, cocoa and the likes which will in turn change the economic position of the state for better.

\section{Threats to Real Estate Investment Prosperity in Ekiti-State}

\subsection{Poor Real Estate Financial System.}

Unlike what operates in the developed nations of the world like U.K, U.S.A and Canada to mention a few where there are standard real estate financial systems, the case is negatively different in Ekiti State in particular and Nigeria in general. Findings revealed that commercial banks are not ready to give long term loan and where loans are advanced at all, they are usually advanced at unbearable interest rate between 23-28\%. The National Housing fund and Bank of Industries that are supposed to be of help are unreachable to the low and medium classes.

\subsection{Political Interest}

Findings revealed that successive governments were interested in short time projects, hence, seem not to believe in continuity. Investing in real estate as a long enduring projects like development of rental housing and Agricultural land have not been addressed with the seriousness they deserve. 


\subsection{Absence or lack of developable land.}

Research showed that the volume of developable land within the metropolis of Ado-Ekiti which forms the commercial and administrative nerves of Ekiti State is drastically limited viewing it from Ilawe, Ikere, Ijan, Iyin or Iworoko. Ado-Ekiti seems not to have enough land meant to create wealth for its ever increasing population.

\subsection{Low Federal Allocation and IGR.}

It is a statement of fact that the onus of land development rests solely on the government. However, findings showed that the Internally Generated Revenue (IGR) of Ekiti State is generally low. It has also been variously argued that Ekiti is the $2^{\text {nd }}$ lowest Federal Allocation receiving state. This in most cases tends to cripple the Government in rolling out programmes that will encourage real estate investment.

\subsection{Poor Integration.}

It has been declared that activities and attitude of government has made its critics to believe that only two cities exist in Ekiti State, that is, Ado-Ekiti and others. In the area of physical development, too much attention is seen to be concentrated in Ado Ekiti at the detriment of the development of other parts of the state. This in turn has increased the rural - urban drift.

\subsection{Absence of reliable property data bank.}

It is variously argued that much have been said about the need for proper and efficient land administration in Nigeria through comprehensive Land information system but little or nothing has been put in place in Ekiti State. Land administration in the area of proper titling and recording seem to be at the lowest ebb.

\subsection{Poor land Infrastructure.}

Essentially, in most cases where government cannot dabble into physical land development, the option of making available service lands is usually adopted. In Ekiti State in general and Ado-Ekiti in particular, provision of infrastructure is generally poor and far below standard.

\section{Recommendations}

In order to fully harness the residual value and benefits embedded in real estate investment as a veritable source for wealth creation, the following are recommended toward efficient and effective land administration in Ekiti thereby enhancing land resource appreciation and productivity.

9.I Allocation of land should be liberalized and transparent. A system whereby people in government only and their cronies have access to land allocation cannot ensure effective and efficient use of land. They secure the allocations and keep the land undeveloped for years waiting for the price to go up before they sell. The result is that undeveloped plots exist side by side with fully developed ones creating underutilization of amenities and facilities. Ekiti State Government does not have any Land Use and Allocation Committee as prescribed by the Land Use Act. The governor alone therefore handles the allocation of land to whoever pleases them. This cannot lead to an effective and efficient use of land! 
9.2 Simplify the process of transfer to title land. A situation whereby it takes six months to one year to obtain governor's consent to transfer land cannot guarantee effective and efficient use of land. It can delay or even kill many good projects.

9.3 Acceleration and simplification of the process of obtaining planning approval for developments. In most cases, it takes too long to get approval to develop your property even though your design conforms with all the necessary rules and specifications. The process is riddled with so much corruption that designs which do not meet all the rules are the ones that get approval first while the legitimate ones suffer if the owner is not ready to settle the officials. Government can reduce this by selling model designs to the public with room for slight modifications. This can reduce or remove completely the rigors people go through before their building lands are approved.

9.4 Enforcement of approved building plans. Again, a lot of people design correctly only to secure approval but turn round to build something else why the officials responsible for the monitoring turn their eyes elsewhere. This has been responsible for many building collapsing all over the country! We cannot have effective and efficient use of land if buildings are not built according the approval

9.5 There is also the need to upgrade decaying areas and if need be carry out redevelopment of slums and derelict areas. It is expedient to assert that most of our cities have emerged by a process of growth by accretion, that is, without prior plans! For effective and efficient use, there may be need to open up areas where there are no access. Construct centres where there are none.

9.6 Need for improved mass transportation. People do not just move about. They are either moving from residence to work or vice versa or to recreation areas. Therefore good transportation system must be synchronized with the pattern of land use. We can redirect the movement of people by relocation of the target of their movement. Essentially, the growth of sub-centres should be encouraged in a city rather than the idea of a town centre where everybody goes to whenever they need something. This will not only reduce traffic congestion, it will reduce man hours wasted in such traffic and petrol consumption. It will also reduce accidents and health hazards.

9.7 Beautification of open places. Whoever has been to Lagos prior to the last two years can attest to what government has done with spaces that hitherto constituted eyesores and abode for area boys and thieves. These places are now cleared and planted with grass and flower giving beautiful scenery. The planting of the grass and flowers and maintenance of them are sources of employment. This is a very good example of effective and efficient use of land. This can also be replicated in Ekiti State.

9.8 There is need for comprehensive land reform in the area of land titling. Government must put necessary machinery in motion to ensure that every land within the state has title. The ground rent that will accrue to the coffers of Government will go a long way in defraying public expenditure. To the land owner it will upgrade the instrument on the land. The Land Use Act needs to be reviewed and / or removed from the constitution to pave way for the implementation of laudable land related initiatives.

9.9 There is need to establish a functional real estate finance system. Government can float a primary Mortgage Institution in order to assist individual and group to benefit immensely. The housing loan disbursed currently is nothing to write home about.

9.I0 Need to establish a virile legal framework for the efficient and effective of property tax system. The four cannons of Taxation must be followed. The executive must try as much as possible to involve professionals rather than contracting them to political friends who know little or nothing about property taxation.

9.I I Need for efficient and prudent use of Rural Land for Agricultural purposes. Findings had shown that successive governments had not been doing enough in this respect. Ekiti state has enough land for different types of cultivation. Apart from providing food for all and foreign exchange, it will also assist in curbing the rural-urban drift. 


\section{I0. Conclusion}

It is clear from this discourse that an effective and efficient land administration in Ekiti in particular and Nigeria in general will inter alia lead to better use of land resources, improved revenue for Government, wealth creation and its improved distribution, efficient rural and urban management and improved rural and urban quality. This will also provide conducive environment for private developers to operate.

Land is a natural resource that existed before mankind came to being. Land values are created by the whole community because of our need to use land for housing, education, public services, agriculture, mining, business, transport and recreation. Land owners do not create land values. It is the efforts of others that generate land values.

Expenditure on public services usually leads to an increase in land value. The policy framework which includes legal for effective administration of land and landed property must be carefully taken care of. This would go a long way in ensuring land appreciation as well as other subsisting resources.

Real estate without prejudice if well managed will foster economic prosperity in Ekiti State in particular and Nigeria in general.

\section{References}

Akomolede, K (2009): Effective and efficient use of land for wealth creation. MCPD, Ondo State Branch of NIESV

Aluko, B.T (2005): Building urban local governance fiscal autonomy through property taxation financing option. International Journals of Strategic Property Management 9, 20I-2I4

Arayela (2003): Panacea for increasing housing stock at reduced cost in Nigeria. African Journal of Development Studies 3(I) pp I2-I6

Ariyo, A (1997) Productivity of the Nigeria Tax System: 1970-I990 AERC Research paper 67 Africa Economic Research Consortium, Nairobi - Kenya

Bichi K.M (2002): Housing the Nigerian population: Problems and prospects. Journals of the Federal Mortgage Bank of Nigeria I(5) pp 30-3I

Childress M.D, Hansen P., Solomon D and Brink R (2007): Taxing Agricultural Land: A Policy Instrument for Land Use Intensification. Local Development and Land market reform Background paper on WBI/SADC workshop on land redistribution (ebourguignon@wolrdbank.org)

Deininger K. (2005): Land policies for growth and poverty reduction: Key issues and challenges ahead.

European Union (EU) Task force on Land Tenure (2004): EU Land Policy Guideless Guidelines for support to land policy design and land policy reform processes in developing countries

Land Institute (1974): Site Value Rating. The Land Institute, London

Ogedengbe, P,S (2004): Formulating a good urban land policy for Nigeria. Jhum.ecol I5(2): 9I-96. Kamla-Raj

Ojo O. (2009): The Nigeria Tax System: The challenges of decentralization and local government autonomy. Paper presented at a workshop on property tax system and local government financing. Ibadan, Oyo State, Nigeria. $2^{\text {nd }} J$ uly

Ojo, O (2009a) Effective Land Taxation and Administration for Wealth Creation. MCPD, Ondo State Branch of NIESV

Ojo, O (2009b): Community Development: Issues and Challenges. Lecture Delivered at the Self Help Fund raising programme at Kuta, Osun State, Nigeria II ${ }^{\text {th }}$ April

Olaifa K (1988): Nigeria Debt tops in Africa. National Concord Newspaper, June 4

Olajide S.E and Alabi O.T (2012): Elements of Estate Management and Property Valuation, Abisam Prints, Lagos, Nigeria.

Olajide, S.E \& Onifade F.A (20II): Empirical study of Housing poverty in Ado-Ekiti. Environ-Link Journal, Federal Polytechnic, Ado-Ekiti. Volume 3 No I pp I I-20 
Olotuah A.O (2000): Housing low income civil servants in an emergent state capital-The case study of Ado-Ekiti, unpublished Ph.D Thesis, Federal University of Technology, Akure, Nigeria

Olotuah A.O and Adedeji Y.M.D (2009): An evaluation of accessibility of low income earners to housing finance in Nigeria, published in "The Nigeria Housing Perspective"

Omojinmi I.O. (2000): SINA Technical Workshop on Housing Cooperatives, Nairobi, 6-17 $7^{\text {th }}$ October

Onibokun A,G (1990): Urban population, urban Housing in Nigeria, Onibokun A.G (Ed) NISER, Ibadan pp 3957

Wilks H.M (1973): Site Rating: A Practical exercise. Estate Gazette 228EG249, 25I-2 